\title{
MEMÓRIAS DE INFÂNCIA DE PROFESSORAS DA REDE MUNICIPAL DE ENSINO DE CURITIBA E SUAS REPRESENTAÇÕES SOBRE EDUCAÇÃO E ARTE $(1970$ - 1990)
}

Daniela Gomes de Mattos PEDROSO ${ }^{1}$

\begin{abstract}
Resumo
Este artigo apresenta os resultados obtidos em minha investigação de doutorado em Educação, com o objetivo de analisar as representações da educação e da arte presentes nas narrativas de memória de infância de professoras de Arte da Rede Municipal de Ensino (RME) de Curitiba. A perspectiva metodológica utilizada visou compreender as representações da arte presentes nas narrativas de infância das agentes. Com relação aos referenciais teóricos, utilizei os conceitos de habitus, capital cultural e produção do gosto de Pierre Bourdieu e de educação do sensível de Duarte Jr. Além desses, o conceito memória foi considerado central nessa pesquisa e as contribuições de Halbwachs foram basilares nesse contexto. Como resultado alcançado, a constatação de que as representações da arte e educação traduzidas nas memórias de infância dessas professoras em várias dimensões, como a escola e o lar, guardam elementos ligados à concepção de educação do sensível.
\end{abstract}

Palavras-chave: Educação do sensível. Ensino de Arte. Infância.

\footnotetext{
${ }^{1}$ Doutora em Educação pela Universidade Federal do Paraná. Mestre em Educação pela Universidade Tuiuti do Paraná. Graduada em Educação Artística - Licenciatura em Artes Plásticas - pela Universidade Federal do Paraná e especialização em Psicomotricidade pela Fundação da Universidade Federal do Paraná. Professora de Ensino Superior/Curso de Pedagogia, Faculdade Fidelis. Orcid 0000-0001-8947-7363.

E-mail: danielapedroso@hotmail.com
} 


\title{
CHILDHOOD MEMORIES OF TEACHERS OF THE MUNICIPAL EDUCATION NETWORK OF CURITIBA AND THEIR REPRESENTATIONS ABOUT EDUCATION AND ART (1970 - 1990)
}

Daniela Gomes de Mattos PEDROSO

\begin{abstract}
This article presents the results obtained in my doctoral research in Education, with the objective of analyzing the representations of education and art in the narratives of childhood memories of art teachers of the Municipal Education Network (RME) of Curitiba. The methodological perspective used aimed to understand the representations of art in the agents' childhood narratives. Regarding theoretical references, the concepts of habitus, cultural capital and production of taste by Pierre Bourdieu and education of the sensitive of Duarte Jr. were used. In addition to these, the concept of memory was considered central in this research and Halbwachs' contributions were fundamental in this context. As a result, it was observed that the representations of art and education disclosed in the childhood memories of these teachers, in various dimensions such as school and home, keep elements related to the conception of education of the sensitive.
\end{abstract}

Keywords: Education of the sensitive. Art Teaching. Childhood. 


\title{
MEMORIAS DE INFANCIA DE PROFESORES DE LA RED MUNICIPAL DE ENSEÑANZA DE CURITIBA Y SUS REPRESENTACIONES SOBRE EDUCACIÓN Y ARTE (1970 -1990)
}

Daniela Gomes de Mattos PEDROSO

\begin{abstract}
Resumen
Este artículo presenta los resultados obtenidos en mi investigación de doctorado en Educación, con el objetivo de analizar las representaciones de la educación y del arte presentes en las narrativas de memoria de infancia de profesoras de Arte de la Red Municipal de Enseñanza (RME) de Curitiba. La perspectiva metodológica utilizada tuvo por objeto comprender las representaciones del arte presentes en las narrativas de la infancia de los agentes. Con respecto a los referenciales teóricos, utilicé los conceptos de habitus, capital cultural y producción del gusto de Pierre Bourdieu y de educación de lo sensible de Duarte Jr. Además de eso, el concepto memoria fue considerado central en esa investigación y las contribuciones de Halbwachs fueron fundamentales en ese contexto. Como resultado logrado, la constatación de que las representaciones del arte y la educación traducidas en las memorias de infancia de estas profesoras, en varias dimensiones como la escuela, el hogar, guardan elementos vinculados a la concepción de educación de lo sensible.
\end{abstract}

Palabras clave: Educación de lo sensible. Enseñanza de Arte. Infancia. 


\section{Introdução}

Este é um estudo sobre memórias de infância de professoras da Rede Municipal de Ensino de Curitiba e sobre como a educação e a arte se fazem presentes nas suas recordações do passado. Para me aproximar dessas histórias, entrevistei mulheres que, embora de idades e origens distintas, tinham em comum o mesmo espaço profissional: as aulas de Arte².

As professoras pesquisadas apresentam histórias de vida peculiares. No entanto, no período de infância, todas vivenciaram experiências significativas relacionadas à educação do sensível. Essas experiências foram mediadas ou compartilhadas por familiares, vizinhos, colegas de escola, professores e até mesmo por estranhos, em situações de vida geradas em contextos diversos: em cidades do interior do estado do Paraná e de outros estados, em sítios na zona rural, como também na Curitiba de épocas díspares.

As memórias dessas professoras evocam pessoas e momentos que marcaram de alguma maneira suas vidas, seja pela presença ou ausência, pelos caminhos indicados ou percorridos. Em todas elas, as marcas do passado se revelam em acontecimentos, objetos, lugares e pessoas que voltam à cena em um simples recordar. O tempo para quem rememora é regido por outro compasso. Tem o tempo da saudade, do bem querer e da vontade de voltar a ser criança. Mas também há o tempo da tristeza, das perdas e do querer esquecer. Para todos esses, existem sentidos próprios, com significados específicos. E é sobre a sensibilidade, e o que pode provocar o sentir, que esse estudo trata.

Sentir, todos nós sentimos algo por alguma coisa. Porém, não é a esse sentir relacionado às emoções que me refiro nesse estudo, mas à perspectiva de perceber por meio dos sentidos, ou seja, aquilo que captamos e interpretamos; o que nos dá sentido e nos afeta e, principalmente, o que possibilita nos relacionarmos expressivamente com o meio que nos cerca. Assim, as memórias dessas professoras transbordam o sentir na perspectiva estética, seja nas recordações de determinadas situações vivenciadas, nos lugares por onde passaram ou em experiências compartilhadas com outras pessoas.

Nesse sentido, este estudo demandou uma aproximação com as trajetórias pessoais de professoras de Arte da Rede Municipal de Ensino (RME) de Curitiba, especialmente os primeiros contatos delas com manifestações artísticas no período da infância, na família ou no campo educacional, no sentido de analisar as representações da educação e da arte presentes nas narrativas

\footnotetext{
${ }^{2}$ Quando me referir ao componente curricular, grafarei Arte; nos demais casos, arte. O mesmo ocorre na utilização dos termos ensino de Arte e ensino da arte. O primeiro refere-se ao componente curricular de ensino; o segundo, ao ensino da arte de forma geral e em diferentes instâncias.
} 
de memórias desse período, uma vez que as marcas destes percursos de vida podem contribuir para a compreensão das concepções de arte, cultura e ensino de Arte do período em questão.

O estudo levou em conta o recorte temporal que compreende o período de 1970 a 1990, correspondente à infância das professoras de Arte da RME, mais especificamente o período dos 6 aos 14 anos de idade, em que foram alunas na Educação Básica. A escolha deste recorte temporal se justifica por compreender a infância da maior parcela das profissionais que atuam hoje com Arte na Rede, além de oportunizar a análise de um contexto que perpassa duas décadas.

A pesquisa buscou dar visibilidade e voz ao protagonismo feminino no magistério da Rede, especificamente às professoras de Arte, que são e sempre foram maioria em seu quadro funcional. Outro aspecto abordado refere-se à presença ou não de distinções de gênero nas narrativas das professoras referentes às suas vivências artísticas e culturais de infância. Ou seja, se vivenciaram experiências marcadas pela diferenciação de gênero, como brincadeiras, atividades e atitudes diferentes para meninas e meninos.

O presente artigo tem como objetivo apresentar os resultados obtidos na investigação em questão, mais especificamente a constatação de que as representações da arte e educação traduzidas nas memórias de infância dessas professoras, em várias dimensões como a escola, o lar, entre outras, guardam elementos ligados à concepção de educação do sensível.

\section{Narrativas pessoais}

Com relação ao método de pesquisa, a escolha pelas narrativas pessoais se deu em função da singularidade do objeto de estudo, as memórias de infância das professoras de Arte. Nesse sentido, a fonte oral, na visão de Garrido (1993), possibilita a construção de um discurso de interpretação histórica completo, rico e complexo, uma vez que propicia a análise e relação com a vida cotidiana dos protagonistas da história: os homens e as mulheres. Paul Thompson (1988) compreende o uso das fontes orais como a democratização da própria história e a vitalização de uma história que devolve às pessoas seu próprio passado com suas próprias palavras, no sentido da devolução do protagonismo perdido em detrimento de outros.

Pensando na aproximação com uma maior diversidade de contextos, referentes às localidades de origem e permanência das professoras na infância, estruturas familiares, grupos de convívio, épocas, escolas que frequentaram, entre outros aspectos observados nesse estudo, em um primeiro momento, foi realizado um questionário online para mapear o grupo de professoras de Arte da Rede. 
O resultado desse processo foi bastante significativo e encorajador, seja em função do número de participantes, seja nas possibilidades de frentes de pesquisa que se abriram em decorrência das respostas obtidas. Levando em conta o tempo para a pesquisa e o aprofundamento necessário, optei pela realização de entrevistas com seis professoras desse universo estudado, cuja seleção teve como parâmetro determinados critérios, entre outros aspectos utilizados na construção do questionário.

Na definição dos critérios, a ideia foi explorar a diversidade entre as professoras pesquisadas para estabelecer permanências e variações entre os contextos percorridos. Nessa lógica, quatro critérios auxiliaram a seleção das depoentes. O primeiro foi pautado na faixa etária das professoras, na busca por abranger idades distintas, cujo período de infância se inserisse no recorte estudado (1970-1990). O segundo está relacionado ao local onde as professoras passaram a maior parte das respectivas infâncias, na tentativa de privilegiar diferentes localidades, como também diferentes épocas vividas em Curitiba. O terceiro está fundamentado na formação superior das professoras, com potencial para contemplação das diversas possibilidades de graduação: as licenciaturas em Arte (Artes Visuais, Dança, Música ou Teatro), Educação Artística ou Pedagogia. O quarto e último critério se relaciona à experiência no magistério e mais especificamente com Arte, tendo em vista a variação do tempo de atuação na função de professora de Arte.

A partir dos critérios elencados, passei a analisar os dados levantados por meio do questionário online. No cruzamento desses dados, foi possível relacionar várias professoras como potenciais testemunhas para a segunda fase da pesquisa: as entrevistas. Porém, é importante ressaltar que a escolha dessas seis professoras, e não de outras, se pauta também no teor das próprias memórias, pelos indícios capturados nos questionários realizados e pelas possibilidades de exploração destes no decorrer da pesquisa. As memórias dessas seis professoras apresentam pontos de convergência e similitudes. No entanto, também mostram autonomia e originalidade em relação aos acontecimentos narrados. Nesse sentido, há possibilidade de estabelecer relações entre elas sem perder de vista suas peculiaridades e suas experiências de individualidade.

Quadro 1 - Resumo dos dados das professoras entrevistadas.

\begin{tabular}{|c|c|c|c|c|}
\hline Professora & Formação & $\begin{array}{c}\text { Tempo que } \\
\text { leciona Arte }\end{array}$ & Idade & $\begin{array}{c}\text { Local onde passou a } \\
\text { infância }\end{array}$ \\
\hline $\begin{array}{c}\text { Lucinéa } \\
\text { Aparecida } \\
\text { Dobrychlop }\end{array}$ & Educação Artística & Mais de 15 anos & Entre 41 a 50 anos & $\begin{array}{c}\text { Curitiba e interior de } \\
\text { Santa Catarina }\end{array}$ \\
\hline $\begin{array}{c}\text { Elisabete } \\
\text { Drechsler }\end{array}$ & $\begin{array}{c}\text { Pedagogia e } \\
\text { Biologia }\end{array}$ & De 6 a 10 anos & Mais de 51 anos & Curitiba \\
\hline
\end{tabular}




\begin{tabular}{|c|c|c|c|c|}
\hline $\begin{array}{c}\text { Josilene de } \\
\text { Oliveira Fonseca }\end{array}$ & $\begin{array}{c}\text { Licenciatura em } \\
\text { Artes visuais/ } \\
\text { Artes cênicas }\end{array}$ & Mais de 15 anos & Mais de 51 anos & $\begin{array}{c}\text { Interior do Rio Grande } \\
\text { do Sul }\end{array}$ \\
\hline $\begin{array}{c}\text { Tania Maria } \\
\text { Rodrigues do } \\
\text { Nascimento }\end{array}$ & Educação Artística & Entre 11 e 15 anos & Mais de 51 anos & Curitiba \\
\hline $\begin{array}{c}\text { Deisemar } \\
\text { Wendt de Souza }\end{array}$ & Pedagogia & De 0 a 5 anos & Entre 31 a 40 anos & Curitiba \\
\hline $\begin{array}{c}\text { Simone Koubik } \\
\text { Bortolanza }\end{array}$ & Educação Artística & De 6 a 10 anos & Entre 41 a 50 anos & Curiba \\
\hline
\end{tabular}

Fonte: dados organizados pela autora, com base no questionário online, 2016.

Além das fontes orais, a pesquisa buscou levantar documentação referente aos períodos e contextos citados pelas professoras entrevistadas, como fotos, cartas e postais, diários pessoais de infância, trabalhos escolares relacionados às aulas de Arte, livros escolares, a legislação vigente relacionada à Educação e ao Ensino de Arte, documentos oficiais do período pesquisado, entre outras possibilidades.

É importante ressaltar que as fontes provenientes de acervos pessoais, como as das professoras pesquisadas ou outros acervos particulares, são de grande importância para o campo da pesquisa, tanto pelas possibilidades de contato com materiais não disponíveis em outros tipos de acervos ou acessíveis ao público em geral, como pela riqueza e potencialidade de frentes de pesquisa que se abrem sobre a cultura material.

\section{As contribuições de Bourdieu}

Alguns conceitos sociológicos de Pierre Bourdieu são basilares nesse estudo, como habitus, capital cultural e produção do gosto, na expectativa de desvelar aspectos como a frequência e a apropriação de bens culturais, relacionados às famílias das professoras pesquisadas.

Por habitus, o autor concebe o sistema de disposições, modos de perceber, de sentir, de fazer, de pensar, que nos leva a agir de determinada forma, ou seja, a matriz cultural internalizada por nós. Nessa perspectiva, o habitus é compreendido como o produto da internalização das condições históricas e sociais realizadas ao longo das trajetórias pessoais sociais.

Conforme Bourdieu (2008b), o conceito de habitus é importante para a análise de atitudes subjetivas capazes de estruturar as representações e a geração de novas práticas. É um princípio mediador, uma noção que auxilia a pensar as características de uma identidade social, de uma experiência biográfica; é um sistema de orientação ora consciente ora inconsciente. Nesse sentido, entende-se habitus como uma matriz cultural que predispõe os indivíduos a fazerem suas escolhas. 
Outro conceito fundamental nesta pesquisa é o de capital cultural, conceito desenvolvido por Pierre Bourdieu em parceria com Jean-Claude Passeron, e que se refere às diferentes condições de acesso aos bens da cultura. Ao utilizarem o termo capital cultural, os autores (2018) fazem uma analogia ao capital econômico. Seu significado remete à produção, à posse e ao consumo de bens culturais socialmente dominantes. O capital cultural pode se apresentar em três modalidades: objetivado, incorporado ou institucionalizado. A primeira modalidade refere-se à propriedade de objetos culturais valorizados (livros, obras de arte, entre outros). A segunda, à cultura internalizada pelo indivíduo (postura corporal, conhecimentos, hábitos, linguagem, entre outros). A última diz respeito à certificação escolar como atestado de formação cultural. As três modalidades serão analisadas nesse estudo.

No que se refere à produção do gosto, Bourdieu coloca sob suspeita a afirmação do senso comum “gosto não se discute” ao declarar que é construído socialmente. Segundo o autor, o gosto e as práticas de cultura de cada um de nós são resultados de um feixe de condições específicas de socialização. Nesse sentido, o gosto cultural é produto de um processo educativo, ambientado na família e na escola e não fruto de uma sensibilidade inata dos agentes sociais. Na obra A distinção: crítica social do julgamento (BOURDIEU, 2013), o autor põe em discussão a variação de gosto entre os segmentos sociais. Analisa a variedade de práticas culturais entre os grupos sociais e afirma que elas, em grande parte, são determinadas pelas trajetórias educativas e socializadoras dos grupos.

A contribuição de Bourdieu, neste estudo, pode ser considerada expressiva, pois os conceitos cunhados pelo autor proporcionam a ampliação das possibilidades de compreensão e relação entre o contexto e as narrativas das professoras pesquisadas.

\section{Outras contribuições}

Da mesma forma, as contribuições de Raymond Williams no campo da teoria da cultura vêm corroborar à perspectiva de Bourdieu. Para ambos, a produção cultural é imprescindível na reprodução da sociedade e está interligada aos conflitos e lutas, cujas marcas modelam a própria estruturação dos modos de dar sentido à vida, seja por meio das criações artísticas, seja em organizações e instituições sociais. Nesse entendimento, para Williams (2011), os diferentes posicionamentos sobre cultura refletem visões do mundo em que vivemos e talham o sentido dado a esta vida e às determinações que não escolhemos. Ela é, segundo o autor (WILLIAMS, 1992), elemento constitutivo de outros processos sociais e não meramente de suas representações ou reflexões. 
A cultura, nesse sentido, deve produzir a realidade, em vez de meramente refleti-la ou representá-la, pois constitui o mundo real à medida que, como força produtiva, interage com ele por intermédio de "práticas significativas", como a linguagem, as artes, a moda e a publicidade, entre outras formas que integram esse campo complexo e extenso (WILLIAMS, 1992).

A arte, neste estudo, é compreendida de forma expandida, o que significa dizer que é considerada como arte toda atividade ou produção humana estética, seja ela popular, erudita, contemporânea, ou de outros tempos ou lugares, entre outras possibilidades. Não está, portanto, sendo ponderado somente o que o senso comum ou determinados autores consideram como arte, ou seja, as manifestações artísticas que ocorrem em espaços sacralizados, como museus de arte, teatros, casas de cultura, entre outros espaços similares, tal e qual denominado por Bourdieu (2007).

Para Dewey (2010), a arte é compreendida como experiência. Em seu entendimento, nenhuma experiência, especialmente a estética, é instantânea. Deve ser um processo desenvolvido ao longo do tempo. A arte nessa perspectiva é algo a ser compreendido, é uma questão de sentidos. Seu conteúdo expressivo está inserido na matéria sensorial sendo, por conseguinte, algo a ser percebido. Assim, a arte "faz algo diferente de conduzir a uma experiência. Constitui uma experiência" (DEWEY, 2010, p. 184).

De acordo com Canclini (1998, p. 23), “o que é a arte não é apenas uma questão estética: é necessário levar em conta como essa questão vai sendo respondida na intersecção do que fazem os jornalistas e os críticos, os historiadores e os museólogos, os marchands, os colecionadores e especuladores”. Essa perspectiva de sistema que o autor apresenta gera a sacralização da arte, apontada por Bourdieu. No entanto, é preciso ter em mente que a arte, enquanto cultura, é constituída pelas práticas coletivas e individuais, ao mesmo tempo em que essas são constituídas por ela. Portanto, as definições e posicionamentos contrários ou contraditórios podem conviver em um mesmo espaço de tempo, em função dos múltiplos olhares e posicionamentos sobre o tema.

Diante do exposto, ampliam-se as possibilidades de experiências estéticas vivenciadas pelas professoras durante o período de infância em espaços diversificados, como feiras, festas populares, circos, entre outros.

Com relação à aproximação e ao entendimento dos sentidos e sensibilidades advindos das vivências das professoras, a produção de Duarte Jr (2001) é basilar nessa pesquisa, uma vez que nos aproxima da Educação Estética, na perspectiva da importância do saber sensível e da complementariedade com o conhecimento intelectivo. O conceito cunhado pelo autor (2001), no qual defende que as experiências sensíveis vivenciadas por todos nós não se restringem à 
contemplação de formas artísticas ou à frequência a museus e espaços culturais. Elas devem principiar por relações dos sentidos com a realidade ao redor, composta por múltiplos estímulos: visuais, táteis, auditivos, olfativos e gustativos. O autor ainda possibilita a compreensão de que o sensível se dá pela experiência e não pela informação pessoal, pela via do intelecto.

\section{Nas memórias da família, sentidos e sensibilidades da arte}

As histórias de vida das professoras entrevistadas são perpassadas por muitas passagens que marcaram sua infância pelo significado ou simbolismo. Porém, nem todas serão apresentadas e discutidas nesse texto por não se tratar de um estudo de biografias e sim de percursos de vida que, de alguma forma, foram sendo contaminados por situações que impulsionaram o sentir estético.

As rememorações da professora Josilene nos são apresentadas em forma de imagens que, aos poucos, povoam nossa imaginação. Como em cenas de vídeo, cada passagem é construída aos poucos e detalhadamente pelas cores e sensações narradas.

Eu tive uma infância que marca até hoje. São de lá as referências que tenho e as de cor são muito fortes. Cor dia, cor noite. Canela é uma cidade muito fria no inverno, mas é quente no verão. Porém, mesmo o quente do verão ainda é frio. De manhã cedo, o ar é gelado e no final da tarde também é. Mas a cor do dia é muito forte para mim. No inverno em Canela, é muito cinza. Mas é um cinza diferente de Curitiba. É um cinza mais branco, porque quando o tempo fecha, vem a neblina. Então, a gente lá no Rio Grande costuma dizer que vêm uma viração. A viração é a neblina, ela vem rodando. A gente percebe ela chegando. Ela chega, e fica tudo escuro. Fica úmido e muito escuro. A gente não enxerga nada à frente. Então, essa coisa me incomodava. Eu não gostava disso. No entanto, gostava quando não tinha essa neblina e principalmente na primavera, que era mais iluminado. Então, a sensação era muito boa, de que o verão estava se aproximando e a natureza estava brotando (FONSECA, 2017).

Para Lucinéa, no observar dos afazeres manuais da madrinha, nasceu sua vontade e necessidade de experimentar a criação. O mundo feminino predominado pelas “manualidades” é uma constante em suas narrativas. Nelas, fios, tecidos e costuras se entrecruzam com as conversas de adulto ao mesmo tempo em que despertam na menina a vontade de experimentar suas próprias criações. Na observação da atividade das mulheres, nascem possibilidades de exploração dos mesmos materiais usados por elas.

A minha madrinha fazia gorros. O resto de lã minha madrinha me deixava pegar para brincar. A gente enrolava aqui, depois amarava bem forte, tirava e cortava fazendo o pompom. Eu criava bonequinhas. Isso eu posso dizer que era uma criação minha mesmo. Eu dava um jeito de amarrar o olho. Uma outra lã para fazer de conta que era a boca. Porque eu não cortava todo. Ficava a parte debaixo como se fosse uma sainha e a parte de cima era só cabeça. Não tinha braços e nem pernas. Eu tinha lá meus oito ou nove anos. Lembro também, que eu enrolava lãs na bonequinha, para fazer de conta que eram roupas (DOBRYCHLOP, 2016). 
Esse fascínio pelos fios e tramas, originário na infância, se faz presente na vida adulta da professora por meio de suas criações como artista plástica e em suas aulas de Arte na Escola Municipal Presidente Pedrosa. Lucinéa é idealizadora e responsável pela “Oficilinha - Oficina de tramar e tecer”. Por incrível que possa parecer, antes da entrevista, a professora não havia relacionado esse interesse pelas "manualidades” com seu passado e suas vivências familiares. No entanto, esse passado revisitado no presente dá indícios que as experiências do sentir de sua infância foram profícuas.

As “manualidades” também fizeram parte da infância da professora Deisemar. Porém, não na perspectiva da experimentação e exploração da técnica quando menina, mas como produção e representação de sua bisavó, dona Otília.

Quando lembro da infância, lembro do carinho da avó, de poder brincar, pular amarelinha. Da minha avó dar novelo de lã para a gente enrolar. De tentar aprender a fazer o tricô, crochê. E do carinho dela. Ela era especial! A bisa viveu até noventa e um anos. Em 2008 que ela faleceu. Então, ainda sinto muito presente, porque ela me apoiou em tudo, no casamento. Conheceu os tataranetos (SOUZA, 2017).

As peças produzidas pela cara senhora ganharam status de relíquia após sua morte, e como tal são guardadas. Por meio dos relatos, é perceptível a dolorosa falta que a importante senhora faz em seu dia a dia. Porém, seu legado e seus ensinamentos permanecem vivos e inspiram a ânsia por saber mais da professora Deisemar. E hoje a delicadeza das peças, que, manufaturadas pela querida avó, são manuseadas com cuidado, respeito e nostalgia.

Já para a professora Simone, o brincar tem um significado especial.

Eu gostava muito de brincar de venda, porque eu queria imitar as mercearias que eu via. O meu irmão fazia para nós coisas que tínhamos ali no quintal. A terra era os produtos que iam ser vendidos por quilo. A gente improvisava aquelas balanças com tijolos, com pedras para fazer o balcãozinho. A nossa brincadeira era aquela coisa muito lúdica. Brincávamos em árvores, meus irmãos tinham umas cabanas em cima das árvores. Nunca consegui subir lá. Eles não deixavam. Eu brincava muito com a minha irmã Ingrid. Eu tinha também os meus momentos assim de solidão. Ficava brincando sozinha. Lembro bem, pegava aqueles sacos de milho que a minha mãe tinha para dar para as galinhas, pegava um monte e tinha um quarto na casa que estava desativado e ninguém usava. Pegava o milho e desenhava com ele. Colocava um milho do lado do outro e ia formando os desenhos. Então, eu fazia aqueles desenhos de burrinho, de bichinho e não gostava que ninguém entrasse lá. Normalmente eu fechava a porta daquele quarto e ele ficava meio que para mim. Outra coisa que eu também fazia, era com as limas que tinha lá. Fazia as liminhas enfiadas no palito de fósforo usado e ia enfiando e ia fazendo esculturinhas. Várias assim. Nesse tempo, lembro que eu ficava observando o quintal. Observava os bichos, os pintinhos, os peruzinhos (BORTOLANZA, 2017). 
Apesar de ter muitos irmãos, as brincadeiras preferidas eram as que realizava sozinha, no jardim de casa, na observação dos animais domésticos, com elementos da natureza e no quartinho de brincar, onde "desenhava com milho”. Essas brincadeiras de infância foram o disparador para sua produção de adulta como artista plástica. Segundo a professora, os "Bichos Urbanos”, série artística de sua autoria, nasceram da observação das atitudes dos seus animais de estimação.

As experiências e vivências do período de infância dessas professoras, como as de muitas outras crianças, são repletas de acontecimentos que produzem sentidos.

Nós íamos muito ao cinema, meus irmãos e eu. O meu pai era mais de ir ao Largo da Ordem, na Feira Hippie. Lembro-me que no sábado de manhã tinham concertos nessa feira e meu pai levava a gente para assistir. Lembro que, na Móveis Cimo, tinham apresentações de teatro. Eram os próprios funcionários que atuavam. Nós morávamos bem em frente e meu pai me levava. Mas eram coisas gratuitas. Nós saíamos muito. Lembro que a gente se reunia no prédio mesmo. Principalmente na época do Natal. Fazíamos as novenas e sempre tinha um que tocava algum instrumento (NASCIMENTO, 2017).

No caso da professora Tania, a família, por meio do capital cultural e do habitus, proporcionou diversas oportunidades no campo da arte e da cultura.

Naquele tempo, lembro-me que festa lá em casa foi à chegada da primeira televisão. Era preto e branca. Para assistir, era até às oito horas da noite. Depois disso era cama, porque daí era coisa para os adultos. Eu tinha recém entrado na escola. Custou para ter televisão lá em casa. A geladeira também custou a chegar. Lá em casa, tudo era na base do custo. O telefone foi comprado em vinte e quatro meses (DRECHSLER, 2017).

É possível perceber nas lembranças de Elisabete a realidade econômica de seus familiares e o emprego das medidas tomadas pelo governo brasileiro na época, para facilitar a compra de produtos nacionais provenientes da expansão industrial.

Os lugares da infância revisitados pelas professoras Lucinéa, Tânia, Deisemar, Simone, Elisabete e Josilene têm em comum, entre outros aspectos, as possibilidades que se abriram de reviver o sentir. A memória possibilita vivenciar sensações, sentimentos e emoções, encerradas no tempo passado, mas que voltam de forma intensa no ato de rememorar.

Nos tempos de escola, em outras vivências fora do contexto familiar, esses lugares se modificam e se ampliam, assim como os espaços, pois os valores, regras, costumes, entre outros aspectos da cultura escolar, se relacionam com os contextos de origem. É sobre esse novo cenário de relações, sentidos, sentimentos, emoções e representações que tratarei a seguir. 


\section{Nas memórias da escola, a presença da arte}

As escolas frequentadas pelas professoras entrevistadas, no período de 1970 a 1990, localizam-se no sul do país. São escolas públicas e privadas, de grande a pequeno porte. Todas seguem o regime de ensino misto, onde meninas e meninos convivem e aprendem juntos. No entanto, não significa que as atividades e conteúdos eram comuns a ambos. É desse universo de singularidades das escolas frequentadas e rememoradas pelas professoras Lucinéa, Tânia, Deisemar, Simone, Elisabete e Josilene que passaremos a participar a partir de agora.

Eu fui estudar no Colégio Nossa Senhora de Lourdes na época, que agora é o Bom Jesus. Ele é em frente ao hospital Cajuru. A diretora, irmã Zélia foi quem me atendeu. Fui muito bem recebida naquela escola. Mas era uma escola cara! A diretora me mostrou o bosque... e a primeira sala que me mostrou foi a sala de Arte. Ela era subterrânea, um salão enorme! Cabiam muitos alunos. Lembro também que de um lado estava ocorrendo aula de dança. Era dividido. Tinha a professora de dança, a professora de pintura, a professora de escultura. Cada professora exercia uma função e fiquei apaixonada! Falei para o meu pai que eu queria estudar naquela escola (NASCIMENTO, 2017).

Com relação à experiência da professora Tânia no contato com sua futura escola, encantamento pode ser o sentimento que a define. A acolhida da irmã Zélia foi de grande importância para ela, uma vez que as experiências anteriores de visitas a escolas públicas da região não tinham sido nada boas. Mas o que realmente encantou a menina foi o ambiente e as possibilidades referentes às aulas de Arte.

A experiência escolar inicial da professora Deisemar é semelhante à de Tânia, pois ambas retêm em suas memórias a relação com religiosas e com a arte.

Eu comecei no prézinho, na Educação Infantil, em num centro social de freiras. Foi lá que descobri o que era lápis de cor e giz de cera. Encantava-me pegar os desenhos, que eu não sabia serem mimeografados para que nós contornássemos, para colar casquinha de lápis... fazer bolinha de papel crepom e preencher o desenho. Isso eu lembro bastante. $\mathrm{E}$ as brincadeiras na areia. A gente brincava ali com potinhos. Do lanche ser gostoso, uma merenda boa. Depois, eu fui para o Colégio Estadual Dom Áttico Eusébio da Rocha. Então, isso de escrever o cabeçalho da escola no caderno é bem marcante! Marcou muito estudar na sala que tinha "O grito do Ipiranga” pintado na parede, com o Dom Pedro no cavalo branco. Bem bacana! (SOUZA, 2017).

Para Deisemar, as rememorações referentes às atividades artísticas têm maior peso que a atuação das religiosas, pois não há nenhuma menção a passagens ou atividades delas em seu testemunho. No entanto, a pintura na parede da sala, retratando um momento histórico da história do Brasil, preservada até os dias de hoje, segundo a professora que continua a frequentar a escola por ser seu local de votação eleitoral, tem um apreço especial. 
Para Josilene, a escola foi estimulante e propulsora da iniciação e experiência com a música.

Eu participava da bandinha rítmica da cidade. Eu tocava xilofone. Mas queria ter uma clarineta, mas a minha mãe não tinha dinheiro para comprara. Então, eu emprestava a da professora. Levava para casa e ficava treinando. Quando não tinha o instrumento, eu desenhava uma clarineta do lado da minha cama, com uma escala musical e tocava ali. Assim, meu divertimento era tocar ali na parede (risos). Quando eu estava com a clarineta da professora, era como um desafio. Aí essa professora, que era de música, fez um coral. Lembro que ficávamos todos na escola sentados cantando e ela passava escutando para ver como é que era a nossa voz. Quando ela passou por mim, ela fez um gesto que não. Aquilo me deu uma dor no coração, porque eu queria muito cantar no coral (FONSECA, 2017).

Apesar da recusa inicial no grupo de coral, as vivências promovidas pela escola mantiveram acesa essa vontade, concretizada mais tarde durante a adolescência, na participação do grupo coral Madrigal, formado por alunas do Instituto de Educação do Paraná, onde passou a estudar.

Eu comecei a copiar os desenhos que estavam na sala de aula: patinhos, etc. Eu olhava e copiava, olhava e copiava. Eu achava que todo mundo sabia desenhar; que todos tinham facilidade como eu. Quando comecei a perceber que eu sabia e os outros não, comecei a ficar famosa na sala. A professora da sala, dona Terezinha, começou a perceber que eu desenhava. E todos os dias ela me pedia para desenhar. Eu tinha que fazer as letras do abecedário. Por exemplo, nós estávamos aprendendo a letra $\mathrm{F}$ e eu desenhava a letra com uma faca embutida. Tinha o lobo. Era tudo assim. E eu adorava fazer isso! Então, fiz o ano inteiro o abecedário para ela (BORTOLANZA, 2017).

Simone, considerada por sua professora e colegas como detentora de dom para o desenho, passou a protagonizar esse privilégio de maneira natural. Aqui é possível identificar a ideologia de “dom”, defendida por Bourdieu (2015), como a crença no talento pessoal e consequentemente maior facilidade para aprimoramento.

Eu tinha uma professora própria para as aulas de Arte. Fiz todos aqueles desenhos mimeografados, lindos, porque a gente nunca tinha visto aquilo. Era o novo. A proposta da 5692 estava lá. E daí a gente pintava, colava serragem, colava sabugo (risos), colava macarrão. Isso desde o primeiro ano. No Pré era mais livre. Quando fui para o primeiro ano, foi mais marcante esse trabalho de arte. Era uma aula normal, em que em alguns momentos a gente parava para pintar essas coisas, para colar. Mas pintar nem tanto. De teatro e dança, nada (FONSECA, 2017).

As rememorações de Josilene apresentam o panorama inicial da implementação da Lei 5692/71, presente em muitas instituições de ensino na época, contexto em que não se sabia ao certo o que deveria ser trabalhado. Os desenhos mimeografados e as colagens com materiais diversos sinalizam um ensino pautado em atividades artísticas desconexas, na perspectiva de levar os estudantes a experimentarem diferentes materiais e suportes, em atividades dirigidas e comuns a todos, sem a possibilidade de individualização da configuração formal. 
Certamente a referida Lei não avaliava explicitamente esse tipo de prática. No entanto, era uma solução fácil e pronta para os professores que, muitas vezes, desconheciam outras possibilidades pedagógicas em Arte.

Mesmo eu que gostava de arte achava as aulas de Educação Artísticas inóspitas. Lembro uma vez que a professora fez uma atividade assim: 'Hoje vocês vão fazer as expressões faciais’. Daí pensei assim: ‘o que vou fazer?’ Eu tinha uma moeda de um real, peguei o caderno de arte e fiz vários círculos com aquela moeda. Daí fiz várias expressões faciais com os rostinhos bem desenhados, com bonezinho, com cabelinho, com não sei o que lá e colori. Eu me inspirei fazendo aquilo. Vi que a professora gostou. Ficou muito bem feitinho mesmo! Mas esse caderninho de arte se perdeu. Outra atividade também que ela nos mandou fazer era um desenho livre. Ela vivia mandando fazer desenho livre. Fiz um desenho que eu tinha visto numa gravura num livro. Eu lembrei de memória. Fiz um burrinho andando em um jardim e mais alguma coisa que não lembro. Mas fiz aquele burrinho bem do jeito que eu tinha visto. Tentei fazer. E também ela gostou! Lembro que ela me deu 'Ótimo!' (BORTOLANZA,2017).

Apesar de Simone gostar de desenhar, ter sido incentivada durante as séries iniciais por sua professora regente e ter tido em sua casa a liberdade e a possibilidade de expressão por meio de diferentes materiais ao seu alcance, conforme relatado anteriormente, as aulas de Educação Artística na Escola Guido Straube, onde cursou as séries finais, não eram nada estimulantes.

A prática do desenho livre, utilizada com frequência por sua professora, era uma possibilidade de exercitar a criação, uma vez que, em um universo de atividades prontas para colorir, colar ou montar, o desenho livre era compreendido como possibilidade de livre expressão. Porém, difícil ser criativo em meio a tantos modelos prontos que abundavam nas salas de aula da época.

Elisabete e Simone estudaram no mesmo colégio e na mesma época e, portanto, suas aulas de Educação Artísticas tiveram o mesmo caráter.

A aula de Educação Artística, pelo menos no meu tempo, era como se fosse uma janela para que o professor regente pudesse sair de sala e ir planejar alguma coisa. Então, o outro professor estava ali para "encher linguiça”. Era só aquela coisa de desenhar e pintar e estava bom! (DRECHSLER, 2017).

Talvez a reação de indiferença de Elisabete para com as aulas de Educação Artística esteja relacionada à percepção da postura dos professores de pouco estímulo para execução das atividades propostas. Há de certa forma um descrédito na importância dessas aulas, sinalizado pela expressão utilizada de que para o professor qualquer coisa que se entregasse estaria bom.

Lucinéa rememora que a professora Estael explorava em suas aulas de Educação Artística técnicas de desenho e pintura. Porém, as propostas não eram desenvolvidas durante a aula.

A professora Estael dava as técnicas e nós desenvolvíamos em casa. Depois levávamos em uma pasta para ela ver. Então, teve, por exemplo, o desenho que nós tínhamos que desenvolver com o giz de cera, passar para a outra folha com o ferro 
de passar, com o calor do ferro o giz derretia e passava para outra folha. Eram essas técnicas (DOBRYCHLOP, 2016).

Bem diferente das posturas das professoras de Elisabete e Lucinéa, Deisemar rememora a atenção e o interesse de ensinar de forma individualizada de uma professora em especial.

Lembro muito da professora Miriam. Ela me ensinou a pintar, fazia contorno mais forte bem rapidinho e depois com o lápis de ladinho pintava o interior da flor, do urso, de qualquer desenho. Ela que me ensinou a pintar nos limites do desenho para não fazer de qualquer jeito. Ela mostrava os desenhos dela, tinha uma pasta de desenho e ela folheava para a gente, mostrando para as crianças. E a gente ficava encantado! (SOUZA, 2017).

Percebe-se a alusão ao aprimoramento técnico do desenho, bem como para a estética adulta. A professora Miriam mostrava como deveria ser feito para que os alunos pudessem colorir “corretamente" os desenhos prontos: primeiro o contorno depois o preenchimento da imagem. Assim, as crianças não ultrapassariam o limite da linha de contorno e o desenho "não ficaria de qualquer jeito”, pois, nesse entendimento, só havia um jeito de ser feito, do jeito que não ficassem "feio".

As aulas de Arte na escola de Tânia aconteciam semanalmente e as práticas veiculadas eram bem distintas das atividades prontas e datas comemorativas.

Tínhamos aula de Arte durante a semana. Eu tinha aula de dança, com a professora Rosa. Lembro que eu falava assim, "Nossa! sou anã e vou dançar!”. Ela respondia: "Você vai dançar do mesmo jeito!". Ela era formada em Dança e em Educação Física. Eu tinha a professora de desenho e pintura, que era a professora Rocio. Uma excelente professora! Foi por aí que comecei a gostar da arte mesmo. Eu tinha a professora de escultura, que era a professora Gení. A de Teatro, eu não me recordo o nome. E durante a tarde tinham as oficinas, mas eram pagas. Eu estudava de manhã e à tarde tinham as oficinas. O meu pai, como sabia que eu gostava muito de desenhar e pintar, me colocou em uma oficina de desenho e pintura. Comecei na oficina com nove anos. Nas aulas de Arte, nós tínhamos até xilogravura, tínhamos que talhar a madeira. A gente trabalhava sempre em cima de um artista (NASCIMENTO, 2017).

A sala de Arte, desde sua visita inicial à escola, foi motivo de admiração, conforme seu relato anterior. Não só pelas dimensões, mas pelas atividades diferenciadas acontecendo de forma simultânea, pelo fervilhar das turmas em ação e também pela acolhida e atenção recebida das professoras presentes. Quase todas são lembradas pelo nome. E foi nesse contexto que Tânia afirma ter começado a gostar de arte. Nessa escola, ela sentia que podia ir além, que não estaria limitada pelo peso do preconceito. A afirmação de sua professora de dança, Rosa, que ela poderia dançar do mesmo jeito que as demais alunas, bastou para a menina, pois entendeu que seria aceita como era e que sua baixa estatura não seria encarada como empecilho para sua aprendizagem, como já havia acontecido em outras instituições de ensino. 
No que concerne às sensações e reações suscitadas e compartilhadas nas narrativas de memórias dessas professoras, todas passaram pela experiência de frequentar aulas de Educação Artística durante a educação básica. Algumas fazem comparativos com suas respectivas práticas e expressam a frustração de não terem tido na infância a oportunidade de vivenciar a arte de forma mais significativa e consistente. Outras veem nessas aulas oportunidades de novas experiências, mesmo que de forma conduzida e limitada. Em alguns relatos, chegam a emitir juízo das aulas como destituídas de conteúdos referentes à arte propriamente dita, como processos de experimentação artística na perspectiva de desenvolvimento técnico muito mais do que estético. Mas também há quem tenha descoberto nas aulas de Educação Artística motivação para superação, buscando nelas oportunidades de descobertas e aprimoramento.

\section{Considerações Finais}

Depois de passar quatro anos na companhia dessas seis professoras e ter o privilégio de visitar suas infâncias como convidada especial, a despedida se torna difícil. Porém, nessa viagem ao passado, que teve início no momento em que elas compartilharam comigo suas histórias de vida, e agora partilhadas com todos que se dispuserem a ler este artigo, muitos momentos de descobertas, de surpresas, de reconhecimentos e de déjà $v u^{3}$ foram vivenciados.

Muitos desses momentos nos parecem familiares por estarem presentes na infância de todos nós, como as recomendações, as broncas e os castigos, imputados por nossos pais e familiares, ou as brigas com irmãos e primos por trivialidades. Outros, por corresponderem ao que Halbwachs considera como memória coletiva, porque na realidade nunca estamos sós, pois "temos sempre conosco e em nós uma quantidade de pessoas que não se confundem” (HALBWACHS, 2004, p. 30).

Nas experiências rememoradas, foi possível vislumbrar diferentes sensações e sentimentos revividos no compasso dos acontecimentos. Algumas emoções foram libertas no ato de evocar o passado. Cheiros, sons e cores, há muito esquecidos, foram se fazendo presentes na cadência dos fatos recordados.

Mas o mais importante de todo esse processo de reencontro com um passado adormecido foi a possibilidade de concretizar o intento de captar e registrar as vivências significativas dessas professoras, relacionadas à educação do sensível. Cada uma delas teve experiências sensíveis ao longo de sua infância, as quais contribuíram para suas representações de arte. Isso porque tais

\footnotetext{
${ }^{3}$ É quando nós vemos ou sentimos algo pela primeira vez e temos a sensação de já ter visto ou experimentado aquela
} sensação anteriormente. 
experiências transitaram entre o mundo vivido e o pensado, em que a arte se encontra, conforme postula Duarte Jr (2001). Algumas dessas experiências foram apresentadas e analisadas durante o texto. Mas nem todas, em função do volume e do grau de relevância.

No caso das experiências com arte e com a cultura, no período de infância dessas professoras, a diversidade encontrada se relaciona com os contextos socioculturais e espaço-temporais. As representações de arte foram sendo constituídas ao longo de seus percursos de vida e pelas experiências do sensível. Foi possível essa comprovação por meio dos fragmentos de acontecimentos retidos na memória das agentes. Tais fragmentos trazem em seu bojo significados próprios, visto que "o saber carrega um sabor, fala aos sentidos, agrada ao corpo, integrando-se, feito um alimento, à nossa existência.” (DUARTE JR, 2001, p. 14). Nessa perspectiva, o sabor da infância é amplificado pelas representações construídas nesse percurso e que resultam nas concepções de arte, cultura e ensino de Arte do tempo presente.

As representações de arte das professoras pesquisadas, construídas em seus percursos de vida e compartilhadas nesse estudo, são amplas e consideradas positivas. Todas concebem a arte e seu exercício como instigante, como ímpar, como propulsora de ideias e sensações, como forma libertadora de expressão e de fruição. Embora em alguns momentos, no trajeto da pesquisa, a ideia de arte tenha estado relacionada às formas mais eruditas, como as veiculadas em espaços institucionais, essa contradição se justifica pala perspectiva de sacralização da arte, tal qual defendida por Bourdieu (1996). Nesse entendimento, a força das ideias veiculadas pela cultura hegemônica tende a dominar e se fazer presente de maneira automática, em um descuido momentâneo, pelo efeito do arbitrário cultural.

As representações sobre a educação, no caso específico do ensino de Arte, são diferentes e relacionadas às vivências escolares. Para algumas dessas professoras, são sinônimos de descoberta, da busca pelo novo, de superação e de reinvenção. Para outras, trazem à tona conflitos causados pela crença, muitas vezes equivocada, na falta de aptidão ou dom, por não se considerarem possuidoras de inclinações artísticas, ou pela comparação com outros colegas, cujos resultados eram considerados mais satisfatórios por seus professores.

Apesar de algumas professoras realizarem comparativos entre os conteúdos e procedimentos das aulas de Arte que lecionam no presente e as aulas frequentadas no passado, e considerarem essas últimas como restritivas, compreendem que suas experiências de infância são frutos do tempo e dos espaços em questão, e as julgam relevantes em suas trajetórias de vida. Outras, como as professoras Simone e Elisabete, não consideram as aulas de Educação Artística, vivenciadas por 
ambas na mesma escola, como importantes ou significativas. Mesmo assim, veem a escola detentora de destaque relacionado à arte, em função das possibilidades provenientes desse contexto. Independente das experiências escolares serem abrangentes ou restritivas, todas as professoras compreendem a importância da escola como espaço formativo e propulsor de cultura.

Com relação às propostas pedagógicas experimentadas nas aulas de Educação Artística, foi constatado um padrão de atividades técnicas, voltadas à experimentação de materiais expressivos. Isso se justifica em função do recorte temporal e do trajeto do ensino de Arte no Brasil, com exceção da escola frequentada por Tânia, que proporcionava o domínio de diferentes técnicas, porém com a possibilidade de trabalhos mais livres, no que se refere à liberdade de criação. Essa diferenciação pode estar pautada nas características das respectivas instituições de ensino. Com isso, não se quer concluir que a escola de Tânia tinha uma visão diferenciada sobre arte e cultura por ser particular, mas que sua história e tradição de origem contribuíram nesse aspecto.

As demais escolas frequentadas pelas professoras entrevistadas eram públicas e, portanto, pertencentes às Redes de Ensino dos respectivos estados do Paraná e do Rio Grande do Sul. A prioridade inicial das redes públicas, de uma forma genérica, era ofertar ensino básico à população de baixa renda. Por esse ensino, compreendia-se a aprendizagem da língua materna, as operações básicas, noções de história e geografia. Assim, a arte só veio fazer parte do currículo oficial dessas escolas com a Lei 5692/71, salvo em caso de regionalismos ou práticas culturais contextualizadas observadas em algumas instituições públicas, como, por exemplo, as tradições gaúchas.

Nesse entendimento, é possível concluir que a origem e o percurso dessas instituições de ensino contribuíram para as respectivas concepções e práticas culturais e artísticas, por conseguinte, para o formato específico das aulas de Educação Artística.

Conforme a rememoração das professoras, o foco primordial dessas aulas era as Artes Visuais. A Música aparece com frequência nos relatos como a segunda linguagem artística mais trabalhada de forma curricular. Já o Teatro e a Dança têm participação curricular bem menor. Muitas vezes o Teatro é mencionado como estratégia metodológica vinculada a outras disciplinas e a Dança como atividade cultural relacionada às festividades escolares.

É importante relembrar que o contexto do ensino de Arte durante o período temporal estudado, de 1970 a 1990, perpassa por alterações na legislação que incidem diretamente sobre esse ensino, a Lei n. ${ }^{0}$ 5692/71, que introduz a Educação Artística no currículo escolar do Ensino Fundamental e Médio, e o Parecer 540/77, que busca orientar sobre a função de seu ensino. No entanto, nessas duas décadas estudadas pouco se percebe de diferente nas práticas rememoradas 
pelas professoras. Isso se justifica em função do tempo necessário de adaptação às novas perspectivas educacionais e de construção de um componente curricular.

Além disso, deve-se levar em conta o contexto sociopolítico que nesse mesmo período passa, de uma ditadura à democratização do país, o que interfere diretamente nas práticas escolares e nas dinâmicas familiares, porém a seu tempo. As mudanças não ocorrem de forma automática, sendo incorporadas de acordo com as necessidades e possibilidades de cada realidade.

Fizeram parte do percurso das professoras não só as experiências do sensível por elas vivenciadas, mas também o habitus, em suas diferentes classificações, que contribuiu na formação do gosto e nos respectivos capitais culturais, na perspectiva de Bourdieu (2008, 2009, 2013). Diferentes mediadores culturais tiveram lugar nessas histórias de vida. A família e a escola podem ser consideradas as principais, de acordo com os testemunhos das professoras. Porém, outros também foram identificados, a mídia para muitas delas.

As distinções de gênero foram vivenciadas em diferentes contextos e estão presentes nos relatos de todas elas: nas atividades diferenciadas para meninas e meninos na escola, nas brincadeiras de rua ou nos afazeres domésticos.

A atuação de protagonismo feminino identificada vai além do pretendido no início da investigação, com o foco no magistério. Realmente, as mulheres sempre foram em número maior que os homens no quadro da RME Curitiba, conforme comprovado durante o estudo, e atuaram no sentido da construção de um campo de docência. Nas rememorações das agentes, as professoras também são maioria, os professores começam a figurar em seus testemunhos somente no contexto dos anos finais do Ensino Fundamental, principalmente, relacionados às aulas de Música, no que se refere ao ensino de Arte.

No entanto, o protagonismo feminino também foi constatado nas relações familiares. A presença feminina tem um peso muitas vezes maior, em termos de representação e simbolismo, do que a masculina. Dessa forma, assevero a possibilidade que esse estudo concretizou: procurar os vestígios das mulheres na história e “ouvir suas vozes - as palavras das mulheres " (Perrot, 2017, p. 31), pois, se sempre estiveram lá, por que pouco se tem registrado sobre seus pensamentos e sentimentos enquanto mulheres, filhas, mães, alunas, profissionais, professoras?

Para que as vozes dessas professoras fossem ouvidas e não se tornassem genéricas, foi necessário adotar na pesquisa o não anonimato. Foi preciso assumir seus nomes, compartilhar suas imagens e objetos pessoais, expor seus familiares e as passagens de suas vidas. A escolha de se

\footnotetext{
${ }^{4}$ Grifo original.
} 
assumirem como protagonistas implicou em muitos desafios. Além do ato de coragem necessário a esse intento, também o desprendimento de depositar confiança em minha pessoa. Espero ter correspondido e feito bom uso dessas memórias no sentido de pensar a história e de ter trazido problematizações relevantes para refletir sobre a História da Educação.

Quanto às manifestações artísticas e culturais vividas na infância por essas professoras, embora a princípio algumas pensassem serem poucas, no exercício da memória elas foram se avolumando e de certa forma até surpreendendo pela quantidade e representatividade. Talvez isso se dê pelo esquecimento temporário ou até pelo fato do conceito de arte e cultura a princípio se apresentar mais restrito. Porém, com o exercício do rememorar, ele foi se alargando e se moldando ao volume de experiências passadas. Nesse entendimento, o acervo de manifestações vivenciadas perpassa do popular ao erudito, em contextos variados como o lar, a rua, a igreja, a escola e outros lugares.

Talvez o mais importante nesse trajeto realizado pelas experiências estéticas vivenciadas pelas professoras no período da infância, quer no campo educacional ou familiar, não seja o caráter em si dessas vivências, ou como e por quem foram possibilitadas, mas seu caráter de propulsoras de representações da arte. Se, no caso da escola, elas foram superficiais, equivocadas, desconexas, enriquecedoras, desafiadoras ou indiferentes, o fato é que são constituintes de suas representações de arte, seja pela configuração diferente da sala de Arte, pela possibilidade de poder sentar com outros colegas, pelo acesso aos materiais artísticos, pelo tratamento dispendido pela professora, pela oportunidade de assistir as apresentações dos colegas, seja por conhecer outras formas de expressão, ou outras possibilidades. O que importa é que de alguma forma as aulas de Arte ou as manifestações culturais escolares têm lugar afetivo e sensível para todas elas, sendo lembradas por isso. Caso contrário, estariam relegadas ao esquecimento.

No caso das professoras pesquisadas, as representações de educação e de arte se entrelaçam, visto que grande parte delas foi construída no contexto escolar. Muitas delas têm origem nas aulas de Arte, outras tantas em passagens na sala de aula com as professoras regentes, em atividades culturais promovidas pelas respectivas escolas e em situações diversas no interior dessas instituições. Porém, outras vivências extraescolares também foram consideradas propulsoras do contato com a arte.

As vivências em família propiciaram experiências distintas entre as professoras, como o contato com a música, o conhecimento da história e do patrimônio público da cidade, a aproximação e a paixão pela literatura, as manualidades, o cinema, entre outras. Porém, em um primeiro momento, algumas dessas atividades não foram identificadas pelas professoras como 
experiências estéticas, talvez por acreditarem tão corriqueiras e familiares que não se deram conta ou não pensaram a respeito como propulsoras desse viés.

As vivências do sensível deixaram suas marcas de uma forma ou de outra na vida dessas professoras. Para a maioria delas, foi necessário, depois de adultas, buscar a ampliação dos referenciais estéticos, por meio da formação superior em uma ou mais das licenciaturas artísticas. Para as demais, a docência em Arte pode ter acontecido sem que tivessem buscado por ela. Porém, não foi por acaso que tornaram essa possibilidade temporária em escolha definitiva.

A contribuição da presente investigação pode ser apontada especialmente quanto à possibilidade que se concretizou de trazer à tona a história de mulheres professoras, por meio de suas próprias vozes na perspectiva de protagonistas. Por conseguinte, objetivou-se a visibilidade e valorização de seus percursos de vida, a aproximação de contextos geradores de sentimentos e sensações e de suas representações sobre educação e arte. Assim como, suprir a lacuna existente de pesquisas sobre o assunto.

Com relação às imagens e objetos provenientes dos acervos pessoais das professoras pesquisadas, utilizados nesse estudo, é importante ressaltar as possibilidades de análise que se abriram a partir deles, pois, concordando com Burke (2017, p. 25), “são uma forma importante de evidência histórica”. Esses pertences resistiram ao tempo porque foram preservados por alguém. São objetos condutores de perspectivas históricas. Nesse sentido, abrem-se possibilidades e potencialidades de temas para pesquisas futuras sobre a escola, as práticas escolares, a vida cotidiana, entre muitos outros.

\section{Referências}

BOURDIEU, Pierre. A distinção: crítica social do julgamento. Porto Alegre: Zouk, 2013.

A escola conservadora: as desigualdades frente à escola e à cultura. IN: NOGUEIRA, Maria Alice; CATANI, Afrânio. Escritos de educação. Petrópolis: Vozes, 2008. p.39-64.

A produção da crença: contribuição para uma economia dos bens simbólicos. Porto Alegre, RS: Zouk, 2008b.

Letras, 1996.

As regras da arte: gênese e estrutura do campo literário. São Paulo, Companhia das

. O amor pela arte: os museus de arte na Europa e seu público. São Paulo: Zouk, 2007.

. O senso prático. Petrópolis: Vozes, 2009.

BOURDIEU, Pierre.; PASSERON, Jean-Claude de. A reprodução: elementos para uma teoría do sistema de ensino. Petrópolis: Vozes, 2018. 
BURKE, Peter. Testemunha ocular: o uso de imagens como evidência histórica. São Paulo: UNESP, 2017.

CANCLINI, Nestor Garcia. Culturas híbridas. São Paulo: Edusp, 1998.

DEWEY, John. Arte como experiência. São Paulo: Martins Martins Fontes, 2010.

DUARTE JR, João Francisco. O sentido dos sentidos: a educação (do) sensível. Curitiba: Criar Edições Ltda, 2001.

GARRIDO, Joan del A. As fontes orais na pesquisa histórica: uma contribuição ao debate. Revista Brasileira de História. São Paulo: ANPUH/Marco Zero, v.13 n.25/26, set-out.1993, p.33-54.

HALBWACHS, Maurice. A memória coletiva. São Paulo: Centauro, 2004.

PERROT, Michelle. Escrever uma história das mulheres: relato de uma experiência. Cadernos Pagu, Campinas, n.4, p. 09-28, $1995 . \quad$ Disponível em: <http://periodicos.sbu.unicamp.br/ojs/index.php/cadpagu/article/view/1733 > Acesso em: 05 mar. 2017.

THOMPSON, Paul. La voz del passado. História Oral. Valência: Institució Alfons el Magnànim, 1988.

WILLIAMS, Raymond. Cultura. Rio de Janeiro: Paz e Terra, 1992. . Política do Modernismo. São Paulo: Editora Unesp, 2011.

Recebido em: 02/06/2020

Aprovado em: 26/11/2020 